\title{
Alexander Dilger* \\ Personnel Economics: Strengths, Weaknesses and Its Place in Human Resource Management
}

Personnel economics is a rather young academic (sub-)discipline that applies (micro)economic methodology and insights to the personnel function of companies. It is scientifically fertile and complementary to other disciplinary approaches to personnel issues. Instead of that, an approach without a grounding discipline seems dubious and a self-contained personnel science does not exist.

Key words: discipline, economics, HRM, human resource management, labour economics, personnel economics

(JEL: A12, B40, J00M10, M12, M20, M50)

* Prof. Dr. Alexander Dilger, University of Münster, Institute for Organisational Economics, Scharnhorststr. 100, D - 58151 Münster. E-mail: alexander.dilger@uni-muenster.de.

** Many thanks for various suggestions to the participants and organisers, especially Albert Martin, of the "8. Jahrestagung des Arbeitskreises Empirische Personal- und Organisationsforschung (AKempor): Erkenntnisfortschritte in der Personalwirtschaftslehre" in Luneburg, where the author made a presentation on which this article is based. Further thanks to Johanna Metker and Karsten de Ponte for valuable feedback. Of course, only the author is responsible for all expressed opinions and any remaining errors.

Article received: December 12, 2010

Revised version accepted: August 24, 2011. 


\section{Introduction}

Personnel economics is a quite young sub-discipline of human resource management (HRM). HRM will be used in the following as a neutral generic term including all subdisciplines and academic approaches concerning human resources. Since its establishment in the 1990s, personnel economics has strongly developed internationally as well as in German-speaking countries. Wunderer and Mittmann (1983) found only economic trace elements in HRM publications. Sadowski et al. (1994) already saw an economic silver lining at the horizon. Weibler and Wald (2004) complained about economic hegemony in HRM, although there are much less personnel economists than other HRM researchers even though their share is increasing.

In the next section, the meaning of personnel economics is explained. The third section outlines the strengths of personnel economics and the fourth section its weaknesses, both from the author's personal point of view (and confined to Germanspeaking countries). The same holds for explanations concerning the relationship between personnel economics and other sub-disciplines of HRM in section five. One important distinction is made between approaches founded in other established disciplines like psychology or law, which seem equally valid as personnel economics, and those without such a foundation. Section six concludes.

\section{The meaning of personnel economics}

Personnel economics is a fusion of the much older economic sub-discipline labour economics and HRM, which is also an older part of management studies or business administration. In personnel economics, microeconomic methods are used to analyse human resources, especially, but not only, from a firm's point of view. Besides methods and insights of microeconomics in a narrow, neoclassical way, personnel economists make use of human capital theory, new institutional economics and econometrics in order to analyse the business function of personnel in general and the relationship between employers and employees in particular. However, a reduction of personnel economics to no more than three concepts of new institutional economics, namely principal-agent theory, transaction costs economics and property rights theory (cf. Ridder, 2009, pp. 60-73), is too narrow and not justified. In principle, any economic and econometric theory and method can be used to generate positive as well as normative knowledge about human resources.

Personnel economics was founded in the 1990s by Edward P. Lazear. Most relevant in this regard is his textbook "Personnel Economics" from 1995 (Lazear, 1995). Already in 1993 he wrote about "The New Economics of Personnel" (Lazear, 1993). In 1998 his most important textbook, "Personnel Economics for Managers", was published (Lazear, 1998; there are two volumes in German, Wolff and Lazear, 2001, and Backes-Gellner et al., 2001). In the same year Lazear gave the Presidential Address to the Society of Labor Economists about "Personnel Economics: Past Lessons and Future Directions" (Lazear, 1999). Therein he discussed mainly his own work from the previous two decades, but also confessed (p. 201): "Actually, the work in personnel economics goes back much further. The earliest mention in relatively modern literature is found in Slichter (1928)." 
Bruno Staffelbach seems (according to Google Scholar) to be the first author who used the German term "Personalökonomik" (Staffelbach, 1994), insofar as Lazear's meaning of the term is concerned, whereas Franz Oppenheimer (1928, p. $172^{* *}$ ) had already used the expression for an economic analysis of persons instead of nations. Staffelbach (1994) cited previous work by Dieter Sadowski (1989 and 1991), the general discussion by Uschi Backes-Gellner (1993), as well as the economist Gary S. Becker (1964). The less precise German term "Personalökonomie" ("personnel economy") had already been used by Sadowski (1991). The most important originally German textbook about personnel economics ("Personalökonomie und Arbeitspolitik", meaning "personnel economy [or economics] and labour politics") was also written by Sadowski (2002).

German exponents of personnel economics are Dieter Sadowski and Bernd Schauenberg, first of all, as well as their academic offspring and "grandchildren". Both are themselves, Sadowski via Horst Albach and Schauenberg via Helmut Laux and Herbert Hax, academic descendants of Erich Gutenberg, who combined German business administration in general with microeconomic insights and methods after World War II (Gutenberg, 1951, 1955 and 1969). Professorial descendants of Sadowski are Uschi Backes-Gellner, Bernd Frick, Kerstin Pull and Martin Schneider, whereas those of Schauenberg are Michael Beckmann, Silvia Föhr and Matthias Kräkel. Their academic grandchildren with professorships up to now are Alexander Dilger, Christian Grund, Oliver Gürtler, Christine Harbring, Petra Moog, Joachim Prinz and Dirk Sliwka. However, personnel economics is generally accessible to anyone who wants to apply economics to human resources. Other important personnel economists are Dorothea Alewell, although she prefers the term "Arbeitsökonomik" ("labour economics", cf. Alewell, 1996), and the habilitated economist Oliver Fabel.

Moreover, the transition to other sub-disciplines like organisational economics and labour economics is open. The quarrels about personnel economics sometimes seem to be more about labelling than about substance and methods. Many researchers who are not personnel economists or even declared opponents also use economic theory and thoughts at least partially. Conversely, distinct personnel economists are open for other (sub-)disciplines and their insights. Furthermore, many personnel economists do not exclusively represent personnel economics but are organisational or sports economists, too. Finally, most German-speaking personnel economists are or at least have been active at the "Kolloquium zur Personalökonomie", a specialised annual symposium since 1998.

Jürgen Grieger (2004) takes a detailed look from the outside (as he is not a personnel economist himself) at personnel economics and its relationship to the rest of HRM. There have also been several discussions about personnel economics and its relationship to other approaches (see especially Alewell, 1996; Weibler, 1996; Weibler \& Wald, 2004, and the following discussions in the journal DBW, but also Martin, 2004, in this journal). Although this article may stir up that debate again, the author principally agrees with Grieger (2005) that such a controversial debate is more of an obstacle than a remedy for the communication between personnel economists and their opponents. However, this is not the sole aim of that debate or of this article. Moreover, established scholars could hardly be converted by the arguments of the other 
side, not the least because important parts of their human capital would be devalued (see section 4).

\section{Strengths of personnel economics}

The greatest strength of personnel economics is its clear theoretical and methodological foundation. This foundation is, as the name indicates, in economics. Theoretical and empirical methods are combined to generate and test new, preferably general and interconnected findings. The scientific progress is relatively large, at least relative to other approaches concerning HRM. ${ }^{1}$ Personnel economics exhibits academic rigor and practical relevance at the same time. Moreover, personnel economics has many connections to economics and other parts of business administration, especially those with an economic approach themselves, like finance or business economics in general. It can also be linked to other academic disciplines like mathematics, law or sports as well as psychology and sociology. Also, there are no national boundaries for personnel economics, although the topics can be national like labour law or co-determination in Germany. Finally, there are general and teachable methods and results. They make the alumni of studies in personnel economics predictable for employers (for other advantages for graduates and their employers see Backes-Gellner \& Krings, 1997).

This is not the right forum to present individual research results or contents of teaching in personnel economics. To learn more about these, the author refers to the personnel economists named in the last section and their publications. For an overview, see especially Backes-Gellner (2004) or Schauenberg (1996). There is no fixed canon of personnel economics anyway. It is a pluralistic movement which generates new findings and has different perspectives and positions. There is a lively and ongoing debate as to what is the best way to proceed.

It is worthwhile to mention one general point. Personnel economics has in a way rediscovered one half of HRM, namely personnel costs. Other approaches with a stronger focus on human behaviour have shown less or no interest at all because costs are not a behavioural or psychological category, but rather an economic or even commercial category. Naturally, personnel costs are of high importance for business practice as well as business administration in general. Weber (2005, p. 158) and Weibler (1997, p. 128) warn about a one-sided consideration of costs only while personnel economists are just beginning to consider them at all and thereby always view costs together with yield and performance. See also Staffelbach (1997). He does not

1 This is vehemently denied by Martin (2004, p. 205): "Regarding the contents, however, there is nothing particularly exciting. The so-called personnel economics [...] makes many new discoveries of long known phenomena, which in the sallow light of economic theory seem somewhat strange if not to say surreal." However, Martin does not present any evidence for his strong thesis. As counterevidence the author refers to the inventive explanation of seniority wages by Lazear (1979) or the completely new implications of the tournament theory by Lazear/Rosen (1981). A German personnel economists like Dirk Sliwka is also part of the international top league (see only Sliwka 2007a and 2007b), while the author (Dilger, 2002) made a "Rücktransfer zum Theoriefundament" ("revertive transfer to the theoretical foundation") on the national level, which Weibler and Wald (2005, p. 98) claimed to be missing from German personnel economists. 
want to leave the cost side only to accountants, who actually are much better in measuring and booking personnel costs than the performance and value added by employees. The relevant goal for commercial companies is the (maximal) difference between revenue and costs whereas minimal costs can be reached trivially by closing down the firm in most cases. Maximal performance or productivity without respect for costs is uneconomically and ruinous, too.

\section{Weaknesses of personnel economics}

There are not only discussions within personnel economics but also, and much more controversially, about it. On the one hand, personnel economics is affected by fundamental arguments against economics in general. On the other hand, some critics question whether economics can be applied to human resources in a meaningful way.

Concerning the criticism of economics as such, non-economists often do not understand economics correctly (cf. Alewell, 1996, who tries to clarify some misunderstandings). Sometimes economists are attacked for simply being the messenger of unsatisfying truths about economic reality. Other critics believe that economists are the source of all ills analysed by them like scarcity, opportunism (see e. g. Miller, 1994) and crisis.

Nevertheless, the foundations of economics do indeed have some more serious problems in regard to their (missing) empirical content or, conversely, concerning their factual validity. Although, as stated in the last section, personnel economics has a strong empirical orientation, this does not exclude empirical deficits at its paradigmatic core. Some parts, like maximising utility without specification, are very difficult or impossible to falsify. Other, like purely egoistic preferences or complete rationality, have been falsified and thus are simply false, at least literally and without qualifications, as even many economists would admit.

However, the consequences of such falsifications should not be overestimated as Martin (2004) does with reference to Popper (1934). The empirical evidence that is needed to make falsifications depends on theory by itself and is theory-laden. It follows that only single theories can be falsified and not a complete paradigm as such. According to Kuhn (1962), a paradigm can only be replaced by another one which solves at least some problems better than the previous one. Nevertheless, the process of replacement is part of a "scientific revolution" and not completely rational. Most adherents of the previous paradigm cannot be convinced of the new one, but have to die out and be replaced by new academics following the new paradigm from the start. Furthermore, there are degrees of truth or correspondence with reality and often a strictly speaking false approximation to an important truth is of higher value than a definitely true triviality.

Thus, most economic models are idealisations that explicitly do not represent reality completely, which is not possible anyway. In spite of or even for this, these models can generate partial explanations, probabilistic predictions and reasonable recommendations for action. Wolff and Lazear (2001) compare such models to a map that depicts only some important features of reality like large streets and would not be useful if it represented every single detail (see also the often misunderstood instrumentalism of Friedman, 1953). Finally, such falsified or at least problematic assumptions can 
simply be dropped, enabling the development of fairly new kinds of economic models, for example models with altruistic preferences or bounded rationality.

Regarding personnel economics itself, some critics (e. g. Martin, 2004) question the applicability of economics to its subject of human resources. Even if there may be relevant and true economic insights in other sub-disciplines, these critics deny that economics can and should be used to analyse personnel as a productive factor constituted by human beings. However, the moral case against the search for the truth seems to be rather weak, especially compared to other disciplines or even subdisciplines of business administration. If there are any moral problems, they do not concern academic insights (or methods) as such but their use in practice which is in turn a quite different matter. Even in business practice it is hardly conceivable how personnel economics could be abused and turned against employees, especially more than psychological tricks could. Anyway, the moral concerns do not easily go along with the factual ones. One wonders how some critics can simultaneously believe that the insights of personnel economics are morally wrong or at least dangerous and that such insights do not exist. In any case, the last claim seems to be false as a look at the findings and publications of personnel economists shows (see also sections 2 and 3 above).

Nonetheless, some academics repeat the critique of economics in general, namely, that it does not conceive the whole of reality in its great complexity (see two paragraphs above), for personnel economics in particular (see Weibler, 1996; Grieger, 2004, with further references). However, because no theory can fulfil this requirement it is not a valid argument against any theory in particular (cf. Dilger, 2009). In any individual case one may argue that a specific simplification went too far and became an oversimplification, or was altogether wrong. Yet this should better be discussed within an academic discipline instead of in a sweeping way against a complete approach like personnel economics. Moreover, the models and assumptions of personnel economics are quite flexible and might be changed and adapted accordingly. Therefore, many personnel economists make use of behavioural economics which follows the economic paradigm rather than old German traditions regarding behaviour (consequently, Martin, 2004, dislikes behavioural economics, too).

By all means, maximising complexity is no reasonable aim and even closeness to reality is only one goal among others like comprehensibility or generality. However, even personnel economists can admit (cf. Backes-Gellner, 2004, p. 225; Lazear, 1995, p. 2) that personnel economics is better in abstracting than in precise describing and analysing of details, where other approaches of HRM are predominant. This is no contradiction to its empirical strengths (see the last section), but an important qualification. Its empirical methods are mostly, although not completely, quantitative whereas other approaches prefer qualitative methods.

Another limitation of personnel economics could be a possibly falling marginal yield of findings. This may be the case if the most worthwhile research questions have been answered at the beginning and remaining questions become increasingly difficult to answer or are simply less important than the previous, already answered questions. In the worst case, a development towards scholasticism threatens, in which formal requirements and the systematisation of previous insights suffocate academic creativity 
and only very special problems are researched and understood by a few insiders. Hypothetically, the converse trend to data-mining without theory is also possible, but this is more probable for alternative approaches with less theory to begin with. Anyway, a disadvantage for all approaches to HRM is the fact that there is only little exchange between them. It is less evident that the marginal product of research is falling. The next great idea could be just around the corner.

A final limitation of personnel economics is that it better suits some themes than others. Generally, this is true for all approaches, but the themes that fit are different. This is one more argument for collaboration and division of labour between different approaches instead of pointless quarrel. For personnel economics such themes are especially difficult for which scarcity is less important than certain psychological and social factors. One such theme is leadership (yet there are economic approaches to it, e. g. Hermalin, 1998), which is of high practical relevance.

\section{Relationship to other approaches}

Different approaches to HRM do not compete against each other, at least as long as they are tied to established disciplines. Personnel economics is one disciplinary approach founded in economics, labour or personnel psychology is another disciplinary approach founded in psychology. There are other approaches founded in sociology, law and so on. Their explanatory contributions to the common subject of experience, that is personnel, are not substitutive but complementary (cf. Staffelbach, 1997, p. 120, and see also the excellent interdisciplinary textbook from Baron and Kreps, 1999). The personnel economist can learn from the labour psychologist and vice versa. Even if propositions seem to be contradictory they are not, but illuminate different aspects and are grounded in different disciplines where the words have different meanings (see the last section). Trying to understand the differences and similarities inspires further research in both disciplines, separately as well as together and interdisciplinary.

At least when doing business and working in their real companies, managers, human resource representatives and normal employees have to identify the knowledge that is relevant to them. They integrate this knowledge into their decisions that are related to all disciplines because there is only one reality. In this integrative reality definitive decisions have to be made although there are many different disciplines to analyse it from different perspectives. The decision-makers on the company floor can and sometimes have to ponder whether economical, juridical or sociological considerations are most important in particular cases or how they are related to each other (for example economic goals under legal constrains by social means). This can be quite difficult and they can be mistaken, missing their own targets.

While a pragmatic weighing of the findings of different disciplines is sensible and necessary, it is idle to speculate abstractly about the relative academic importance of these disciplines. There may be an inner-academic hierarchy (mathematics is more general than economics and more useful for it than the other way round) or not, but in the end the academic relevance depends on the individual interests of each single academic and student. Also, available resources and capacities are relevant factors, which depend mainly on political decisions that ideally follow the preferences of the persons con- 
cerned, like prospective students, who need university places to study medicine or business administration, or researchers, who need jobs and research funds.

It is not surprising that (personnel) economists prefer (personnel) economics and have a better knowledge of it than of any other (sub-)discipline. This holds for representatives of every other (sub-)discipline accordingly. Nobody would deny a scholar of another discipline his or her higher competence in it or criticise his or her greater preference for it. If different disciplines make distinct predictions in concrete cases, sometimes it is possible to come to an empirical decision (but see the first paragraph of this section), even more so for many questions within one discipline which cannot be decided theoretically. In any case, tests between alternative explanations are more fertile and meaningful than the alleged "confirmation" of one single hypothesis.

A completely different matter than the relationship between personnel economics and its sister approaches to HRM which are founded in other established disciplines like psychology or law is the question of what kind of an approach to HRM there can be without any disciplinary linking. Exponents of such an approach independent of any discipline are for example Rüdiger Kabst (Weber \& Kabst, 2004), Albert Martin (2004), Wolfgang Weber (2005) and Jürgen Weibler (1996; 1997), who plead for a problem-oriented approach. Accordingly, research is not guided by one or several academic disciplines but follows the practical and (however identified) academic problems of personnel as its subject. Weber (2005, p. 155, author's translation) wants "to give priority to the problem- or sphere of activity-oriented approach in the theoretical penetration of the subject over the theory-oriented approach". ${ }^{2}$ This overlooks that one is able to systematise and teach existing theories this way, but can scarcely find or develop new ones. It is nearly tautological that "theoretical penetration" is facilitated by a theory-oriented approach. The different academic disciplines are too deep, extensive and difficult for one person to master them all equally well, whereas one person can still survey the different problems of HRM. Even when this will become too complicated one day as it seems to be the case for business administration in general already, a specialisation to analyse a subset of them with one disciplinary approach like personnel economics seems unproblematic. Conversely, it is unclear how one researcher could theoretically penetrate the whole subject of personnel or single problems of it without any theory or by reasonably using all of them at once.

Anyway, Weber (2005, p. 155, author's translation) is generous and allows individual researchers a disciplinary i. e. theory-oriented approach: "It is acceptable for the individual researcher, but not for a whole discipline like HRM. [...] Thereby one has to admit that there is no instance which can pledge independent and self-reliant researchers to one appointed programme." 3 There seems to be a consensus that HRM

Weber writes in German: "Deshalb wird hier mit Nachdruck die Forderung vertreten, dem problem- bzw. handlungsfeldorientierten Zugang bei der theoretischen Durchdringung des Faches den Vorzug vor dem theorieorientierten Zugang zu geben”.

3 Weber writes in German: "Es ist für den einzelnen Forscher akzeptabel, nicht jedoch für eine ganze Disziplin wie die Personalwirtschaftslehre. [...] Dabei muss freilich eingeräumt werden, dass es keine Instanz gibt, die unabhängige und selbstständige Forscherinnen und Forscher auf ein bestimmtes Programm verpflichten kann." 
should not follow only one approach. The wrong conclusion by Weber and others is, at least according to the author's opinion, to infer from the desired problemorientation and use of many different sources of knowledge for HRM as a whole that the same is best for each individual academic. As at least every economist knows since Adam Smith (1776), the division of labour and specialisation enable huge gains in productivity. Certainly, all relevant fields of activity have to be covered but this happens (more or less and sometimes with a time-lag) even without a central planner because of a higher marginal productivity in underrepresented fields. Single specialised activities might be quite meaningless for themselves, but as part of a larger whole they are much more productive than general tasks without any specialisation. If all researchers researched the same questions in the same way, this would be a big waste of effort. Moreover, the very existence of academic jobs and different disciplines in academia are consequences of the division of labour in society at large.

The author seriously asks which kind of science or scholarship researchers of HRM practise if their work is not linked to any established discipline like psychology, sociology, ethnology or economics. There is no trans-disciplinary or disciplineindependent science or "discipline" of human behaviour ("Verhaltenswissenschaft" in German). The same applies for HRM as there is no "personnel science" as such, distant and distinct from economics and all other disciplines of human behaviour like psychology and so on. HRM or business administration in general can be understood as a pool of all disciplines that are relevant for personnel or business in general instead of being an original part of economics. Yet this does not generate a new and independent discipline by itself. It is an example of coexistence and ideally cooperation of these already existing disciplines and does not exclude that an independent discipline could evolve with its own specific methods and comprehensive insights over time which could not be reduced to those of other disciplines. Finally, such a new discipline would need its own paradigm. However, at least the author cannot make out such original methods and insights or actually an independent paradigm of HRM as yet. This is no denial that researchers of HRM who do not belong to an established discipline could have important insights. They are only lacking a systematic and, by definition, a disciplinary approach to find them. That makes their research more difficult and contingent than that of those firmly anchored in one discipline.

The result so far is that there are different approaches in HRM which are founded in different established academic disciplines. The sum of these approaches can be characterised as HRM itself, while HRM or "personnel science" as an own discipline completely independent of these other approaches does not exist. However, there is a viable alternative to an interdisciplinary understanding of HRM. This alternative is not a completely new and independent discipline but the identification of HRM with exactly one of the disciplinary approaches. In this way, the other disciplinary approaches do not become obsolete but they are seen as auxiliary sciences such as each science is an auxiliary science to many others and uses others as an auxiliary for itself (e. g. economics is an auxiliary science to political science and vice versa).

If one looked for one approach to guide HRM, a nearby candidate could be personnel economics. This economic approach would preserve the unity of economics and business administration. However, there is no compelling reason why another ap- 
proach should not be the guiding one like personnel psychology or labour law, especially since this probably happened in the past and in some parts of business practice, like human resource departments, still happens.

One important objection to this line of argument is that there does not exist any real reason for the dominance of one disciplinary approach over all others. All disciplines that can add something to personnel issues should do so. Quite another question, which will only be posed but not answered here although it may be the reason for the vehement debate about personnel economics, is whether all disciplinary approaches should be equally situated in the faculties of economics and business administration. Perhaps the labour jurists should better conduct their research and teaching at the law faculty (as they mostly do), the personnel psychologists at the psychology department and so on. This does not exclude interdisciplinary and interfaculty research and teaching, but on the contrary requires or even advances them.

By defending a claimed sovereignty of interpretation over HRM, personnel economics may be a good bogeyman because its position is relatively clear, it is growing and is nearest to the rest of economics and business faculties. In German even the names "Personalökonomik" for personnel economics and "Personalwirtschaftslehre" for HRM are very similar and could be confounded by outsiders. This may explain the animosity or even envy of some scholars of HRM who do not follow any disciplinary approach. Drumm (2008, pp. 13-17) constructs an opposition between personnel economics and HRM, such that the first cannot be part of the second and is alien to it. Visible signs of these negative feelings with real consequences have been advertisements of vacant chairs at the University of Trier and the Vienna University of Economics and Business which explicitly declared personnel economists as undesirable instead of positively looking for researchers of other approaches like personnel psychologists.

Conversely, personnel economists have not, at least until now and to the best of the author's knowledge, claimed any dominance over other approaches or had any fundamental problems with them. A scholar who is firmly anchored in one discipline does not have to fear the other disciplines and their scholars, but can profit from their findings and possible cooperation. Accordingly, there are no fierce debates between personnel economists and for example jurists of labour law. The strongest critics of personnel economics are scholars of HRM without a foundation in any other discipline. They are no clear target for detailed critique by personnel economists (or anyone else) themselves because their positions are so vague or at least generic for each of them without a strong common core (cf. Matiaske \& Nienhüser, 2004). Following Kuhn (1962), this is a pre-paradigmatic form of science while economists, psychologists and so on each have one more or less clear paradigm that they apply to the subject of personnel.

\section{Conclusion}

Personnel economics is a young and fertile sub-discipline of economics (and business administration) in general and HRM in particular. Self-evidently, personnel economics cannot solve all academic or even practical problems. The cooperation with other (sub-)disciplines is an example of the advantages of the division of labour. Research 
and teaching independently of any academic discipline as well as the foundation of a completely new and autonomous discipline, however, would have to convince with special findings that at least the author (but probably also Weibler \& Wald, 2004) cannot make out. Yet, personnel economics generated and still generates many interesting findings, enriches and is enriched by other disciplinary approaches and, last but not least, business practice.

\section{References}

Alewell, D. (1996). Zum Verhältnis von Arbeitsökonomik und Verhaltenswissenschaften. Die Betriebswirtschaft, 56(5), 667-683.

Backes-Gellner, U. (1993). Personalwirtschaftslehre - eine ökonomische Disziplin? Diskussionsbeitrag zur Personalwirtschaftslehre im deutschsprachigen Raum. Zeitschrift für Personalforschung, 7(4), 513529.

Backes-Gellner, U. (2004). Personnel Economics: An Economic Approach to Human Resource Management. management revue, 15(2), 215-227.

Backes-Gellner, U., \& Krings, A. (1997). Zur relativen Vorteilhaftigkeit eines personalökonomischen Studienprogramms für die Arbeitsmarktchancen von Personalwirten. In M. Auer \& S. Laske (eds.), Personalwirtschaftliche Ausbildung an Universitäten. Grundfragen, Konzepte und Erfabrungen (pp. 27-47). Mering: Rainer Hampp Verlag.

Backes-Gellner, U., Lazear, E. P., \& Wolff, B. (2001). Personalökonomik: Fortgeschrittene Anwendungen für das Management. Stuttgart: Schäffer-Poeschel Verlag.

Baron, J. N., \& Kreps, D. M. (1999). Strategic Human Resources: Frameworks for General Managers. Hoboken, NJ::John Wiley \& Sons.

Becker, G. S. (1964). Human Capital: A Theoretical and Empirical Analysis with Special Reference to Education. New York: Columbia University Press.

Dilger, A. (2002). Ökonomik betrieblicher Mitbestimmung: Die wirtschaftlichen Folgen von Betriebsräten. Munich and Mering: Rainer Hampp Verlag.

Dilger, A. (2009). Grieger, Jürgen: Ökonomisierung in Personalwirtschaft und Personalwirtschaftslehre: Theoretische Grundlagen und praktische Bezüge. Book review. Betriebswirtschaftliche Forschung und Praxis, 61(1), 125 et seq.

Drumm, H. J. (2008). Personalwirtschaft. 6th edition, Berlin and Heidelberg: Springer Verlag.

Friedman, M. (1953). The Methodology of Positive Economics. In: M. Friedman (ed.), Essays in Positive Economics (pp. 3-43). Chicago: University of Chicago Press.

Grieger, J. (2004). Ökonomisierung in Personalwirtschaft und Personalwirtschaftslebre: Theoretische Grundlagen und praktische Bezüge. Wiesbaden: Deutscher Universitäts-Verlag.

Grieger, J. (2005). Ökonomischer Imperialismus als Krise der Personalwirtschaftslehre? Stellungnahme. Die Betriebswirtschaft, 65(1), 79-82.

Gutenberg, E. (1951). Grundlagen der Betriebswirtschaftslehre, Band 1: Die Produktion. Berlin and Heidelberg: Springer Verlag.

Gutenberg, E. (1955). Grundlagen der Betriebswirtschaftslebre, Band 2: Der Absatz: Berlin and Heidelberg: Springer Verlag.

Gutenberg, E. (1969). Grundlagen der Betriebswirtschaftslebre, Band 3: Die Finanzen. Berlin and Heidelberg: Springer Verlag.

Hermalin, B. E. (1998). Toward an Economic Theory of Leadership: Leading by Example. American Economic Review, 88(5), 1188-1206.

Kuhn, T. (1962). The Structure of Scientific Revolutions. Chicago: University of Chicago Press.

Lazear, E. P. (1979). Why Is There Mandatory Retirement? Journal of Political Economy, 87(6), 1261-1284. 
Lazear, E. P. (1993). The New Economics of Personnel. LABOUR/Review of Labour Economics and Industrial Relations, 7(1), 3-23.

Lazear, E. P. (1995). Personnel Economics. Cambridge, MA: MIT Press.

Lazear, E. P. (1998). Personnel Economics for Managers. Hoboken, NJ: John Wiley \& Sons.

Lazaer, E. P. (1999). Personnel Economics: Past Lessons and Future Directions. Journal of Labor Economics, 17(2), 199-236.

Lazear, E. P., \& Rosen, S. (1981). Rank-Order Tournaments as Optimum Labor Contracts. Journal of Political Economy, 89(5), 841-864.

Martin, A. (2004). A Plea for a Behavioural Approach in the Science of Human Resources Management. management revue, 15(2), 201-214.

Matiaske, W., \& Nienhüser, W. (2004). Sinnprovinzen in der Personalwirtschaft - Befunde einer empirischen Untersuchung. Zeitschrift für Personalforschung, 18(2), 117-138.

Miller, M. (1994). Ellbogenmentalität und ihre theoretische Apotheose: Einige kritische Anmerkungen zur Rational Choice Theorie. Soziale Welt - Zeitschrift für sozialwissenschaftliche Forschung und Praxis, 45(1), 5-15.

Oppenheimer, F. (1928). Alfred Amonns „Objekt und Grundbegriffe“. Weltwirtschaftliches Archiv, 27(2), $167 * *-179 * *$.

Popper, K. (1934). Logik der Forschung. Vienna: Julius Springer Verlag.

Ridder, H.-G. (2009). Personalwirtschaftslebre. 3rd edition, Stuttgart: Kohlhammer.

Sadowski, D. (1989): Beschäftigungspolitik aus der Sicht der Unternehmen. In: H. Scherf (ed.), Beschäftigungsprobleme hochentwickelter Volkswirtschaften (pp. 75-92). Berlin: Duncker \& Humblot Verlag.

Sadowski, D. (1991). Humankapital und Organisationskapital: Zwei Grundkategorien einer ökonomischen Theorie der Personalpolitik in Unternehmen. In: D. Ordelheide, B. Rudolph \& E. Büsselmann (eds.), Betriebswirtschaftslehre und Ökonomische Theorie (pp. 127-141). Stuttgart: SchäfferPoeschel Verlag.

Sadowski, D. (2002). Personalökonomie und Arbeitspolitik. Stuttgart: Schäffer-Poeschel Verlag.

Sadowski, D., Backes-Gellner, U., Frick, B., Brühl, N., Pull, K., Schröder, M., \& Müller, C. (1994). Weitere 10 Jahre Personalwirtschaftslehren - ökonomischer Silberstreif am Horizont: Sammelrezension. Die Betriebswirtschaft (DBW), 54(3), 397-410.

Schauenberg, B. (1996). Personalwirtschaftslehre und ökonomische Theorien. In: W. Weber (ed.), Grundlagen der Personalwirtschaft: Theorien und Konzepte (pp. 341-372). Wiesbaden: Gabler Verlag.

Slichter, S. (1928). Modern Economic Society. New York, NY: Henry Holt.

Sliwka, D. (2007a). Trust as a Signal of a Social Norm and the Hidden Costs of Incentive Schemes. American Economic Review, 97(3), 999-1012.

Sliwka, D. (2007b). Managerial Turnover and Strategic Change. Management Science, 53(11), 1675-1687.

Smith, A. (1776). An Inquiry into the Nature and Causes of the Wealth of Nations. Two volumes, London: W. Strahan und T. Cadell.

Staffelbach, B. (1994). Gibt es in der BWL eine Personalökonomik? Discussion Paper, Zurich, retrieved 01.08.2011, from http://www.business.uzh.ch/professorships/hrm/forschung/diskussionspapiere/Diskussionspapier Nr. 02.pdf.

Staffelbach, B. (1997). Personalökonomik oder die Obsoleszenz der Konkurrenz zwischen Ökonomik und Psychologie in der Personalwirtschaft: Ergänzende Bemerkungen. Die Betriebswirtschaft, 57(1), 119-121.

Weber, W. (2005). Die wissenschaftliche Disziplin Personalwirtschaft auf der Suche nach ihrer Identität. In: T. Spengler, \& H. Lindstädt (eds.), Strukturelle Stimmigkeit in der Betriebswirtschaftslebre: Festschrift für Prof. Dr. Hugo Kossbiel (pp. 151-168). Munich and Mering: Rainer Hampp Verlag.

Weber, W., \& Kabst, R. (2004). Human Resource Management: The Need for Theory and Diversity. management revue, 15(2), 171-177. 
Weibler, J. (1996). Ökonomische vs. verhaltenswissenschaftliche Ausrichtung der Personalwirtschaftslehre - Eine notwendige Kontroverse? Die Betriebswirtschaft, 56(5), 649-665.

Weibler, J. (1997). Personalwirtschaftslehre auf der Suche nach Identität: Replik. Die Betriebswirtschaft, 57(1), 127-131.

Weibler, J., \& Wald, A. (2004). 10 Jahre personalwirtschaftliche Forschung - Ökonomische Hegemonie und die Krise einer Disziplin. Die Betriebswirtschaft, 64(3), 259-275.

Weibler, J., \& Wald, A. (2005). Von Teilen und Ganzen - Zum Verhältnis von Personalökonomik und Personalwirtschaftslehre: Replik. Die Betriebswirtschaft, 65(1), 95-100.

Wolff, B., \& Lazear, E. P. (2001). Einfübrung in die Personalökonomik. Stuttgart: Schäffer-Poeschel Verlag.

Wunderer, R., \& Mittmann, J. (1983). 10 Jahre Personalwirtschaftslehre - von Ökonomie nur Spurenelemente. Die Betriebswirtschaftslebre, 43(4), 623-655. 